\title{
MJN ASSESSING THE COMPETENCE OF NURSES IN RENDERING POSTPARTUM CARE AND ITS EFFECT ON WOMEN'S SATISFACTION
}

\author{
Hadayat A Amasha ${ }^{1 *}$, Shymaa A Abdel-Haleem², Amal M Gamal ${ }^{3}$ \\ 'Department of Maternal Health Nursing and Newborn, Faculty of Nursing, Damietta University, Egypt \\ ${ }^{2}$ Department of Maternity, Obstetrics and Gynecology Nursing, Faculty of Nursing, Port-Said University, Egypt \\ ${ }^{3}$ Department of Maternal \& Newborn Health Nursing, Faculty of Nursing, Menoufia University, Egypt \\ *Corresponding Author’s Email: drtotoa67@yahoo.com
}

\begin{abstract}
Background: Competence of maternity nurses affects directly on the quality of health care and women's gratification or satisfaction. Postpartum quality of care is considered a vital part in promoting maternal and neonatal health and symbolizes the process of nursing care. The aim of this study is to assess the competence of nurses in rendering postpartum care and its effect on women's satisfaction. Methodology: A descriptive exploratory research design was utilized. Setting: Three hospitals affiliated to Ministry of Health and Population were selected for their availability of labour and delivery units. Sample: 300 women in reproductive age and all nurses working in Obstetric/Gynecological wards in the previously selected settings. Tools for data collection: Data were collected using: An observational check list for nurses and a structured interviewing questionnaire for women. Results: The total mean of women's satisfaction was quite high (3.90 \pm 0.62$)$, whereas that of orientation and information was $3.83 \pm 1.00$, advices provision was $3.83 \pm 1.8$ and specific nursing care $1.32 \pm 0.46$. It is evident that women were less satisfied with the specific postpartum nursing care they received. The study revealed that there was a positive and highly statistically significant correlation between satisfaction of post partum women and competences of rendered nursing care. Conclusion: There were a highly statistically significant difference between the competences of rendered nursing care and postpartum women's satisfaction. Recommendations: Competence-based nursing care should be provided after the planned birth for mothers in the postpartum unit. Future studies should focus on postpartum mothers' needs of care that reflect on their satisfaction with the services provided.
\end{abstract}

Keywords: Competence, Postpartum care, Women satisfaction

\section{INTRODUCTION}

Maternity nurses must have the knowledge, attitude and competent skills, required to perform their jobs in a competent manner (Freitas et al., 2014). Increasing competition today in the area of maternal health has significantly impact post-natal care development. The major competitive advantage of health care providers is the availability of high-quality postpartum services (Alsaqri, 2016). Dramatic shifts in the healthcare sector demand that all healthcare services, including nursing, be restructured by questioning the quality of medical services (Sise, 2013). Total quality management requires professional knowledge, skills and the understanding of women regarding the type and level of care they have provided (You et al., 2013).
The quality of postnatal healthcare services can be assessed on the basis of women's opinions and happiness (Mercouris et al., 2013). Their satisfaction is the most significant indicator of quality of treatment and is viewed as a product of healthcare services (Abdel Maqsood et al., 2012). The review of literature has shown that women's satisfaction is not only an indicator of future use of nursing care facilities, but also as an important factor in compliance and progress with remediation (Mohammed, 2016). Women's opinions are the best source for telling the providers about the relevant care, which is why this knowledge can be used in preparing and assessing health care (Alsaqri, 2016).

Tsuboi et al., (2014), described female satisfaction as a degree of consistency between the expectations of 
women for the desired nursing care and their perception of the care provided. Measuring satisfaction gave critical performance details, thus contributing to complete quality management (Goh et al., 2016).

Measuring women's satisfaction with nursing care could be useful in improving the quality of nursing services by promoting preferences for treatment along with the monitoring women's experiences and perceptions of quality (Tang et al., 2013). If the results are unsatisfactory, women would change their treatment and care facilities (Shinde \& Kapurkar, 2014). Females who are more comfortable with their treatment are more likely to follow medically prescribed regimens and therefore add to the positive health effects. More satisfied women are more likely to recommend hospital to their friends and family (Buchanan et al., 2015).

Health-satisfaction surveys are conducted to determine the satisfaction of patients, to know their aspirations, suggestions and feedback, to constantly improve quality in all service times, to examine the impact of socio-demographic and treatment cycles on patient satisfaction. For this purpose, women's satisfaction should be continuously assessed using appropriate, accurate evaluation methods to evaluate the quality of treatment, identify variables that influence care and decide which things should be prioritized and changes in services based on patient response (Tang, et al., 2013; Buchanan et al., 2015).

During the postpartum period, the maternity nurses have a central role in providing women emotional and psychological support (Goh et al., 2016). Knowledge is the fundamental competency of midwifery practices. Besides that, psychomotor skills, the ability to make decisions and communicate are important for midwife practices. Competence would be objectively evaluated through a structured evaluation process, using objective standards of professional practice as metrics of quality, to document an acceptable level of performance (WHO, 2011). Consequently, the results of nursing management research should be used as a measure of the contribution of nursing to the maternity care cycle and this could enable the profession to progress in terms of recognition (Freitas et al., 2014; Alsaqri, 2016; Goh et al., 2016).

\section{Significance of the study}

Post-delivery time is a crucial transition period for both the mother and the neonate (WHO, 2014). Morbidity and maternal mortality are major problems because mothers are prone to developing complications such as hemorrhage, which is the leading cause of death or severe sepsis. The first week of the postpartum period therefore needs top-quality care and monitoring (Herculano et al., 2012).

Women's satisfaction and frustration reflect strengths and weaknesses in their decision about the services (Enabor, Nwaeze \& Ouwasola, 2013). It is determined by the cost of health care, the actions of workers and contact with the care providers (Singh, Parashar \& Lal, 2018). Knowing what skills are and how they can be measured is essential for improving the quality of care (Spector et al., 2012).

In Port-said, there is no information available on the competencies of nurses in general and, in particular postpartum care, therefore this study was carried out to address the following research questions:

1. How competent are nurses in providing postpartum care at selected hospitals in Port-Said City?

2. Are women satisfied about received postpartum care at selected hospitals in Port-Said City?

3. What are the factors associated with competence of nurses in provision of care during postpartum period at selected hospitals in port-Said City?

\section{Aim of the study}

The current study aims to assess the competence of nurses in rendering postpartum care and its effect on women's satisfaction.

\section{METHODOLOGY}

\section{Research design and settings}

Design: In this study, a descriptive exploratory research design was used.

Setting: Three hospitals affiliated to the Ministry of Health and Population were selected for their availability of labor and delivery units, receiving women coming from different areas all over Port Said City.

Sample: The convenience sample of the study was made up of two groups: The first group, 300 women who met the criteria. The second group includes all nurses (50 nurses) who work in $\mathrm{Ob} / \mathrm{Gyn}$. unit at the time of the study.

\section{Inclusion and exclusion criteria}

Women who received prenatal care and were hospitalized for at least 2 nights at the time of data collection, women who received antenatal care and had intended pregnancy; as well as gave birth by caesarean 
section to healthy full term baby, women who were not too confused or ill to complete the questionnaire and agreed to participate in the study were included. Women with previous history of hospital admission were excluded.

Pregnancy intendancy, status of receiving prenatal care, and type of birth, were associated with nursing care satisfaction (McLellan \& Laiddlaw, 2013; Dzomeku et al., 2013; Matejic et al., 2014; Srivastava et al., 2015; Monazea \&Al-Attar, 2015).

\section{Data collection methods and tools}

Data collection tools were used with observational check list for nurses for this research. The structured interviewing questionnaire used consisted of three parts:

The first part dealt with socio-demographic and obstetric data. The second part was adapted from Varghese \& Rajagopal, (2013), the initial scale was updated by the researchers and used to measure the satisfaction of postnatal women with hospital services using a 4-point Likert scale. This section of the resource consisted of 32 statements regarding women's happiness in three areas.

Care areas were classified as follows: Welcome, Orientation and information (5 statements); Comfort, Communication and Values (14 statements), Specific Postpartum Care (13 statements). The maximum score received by an item was 4 for totally agree (fully satisfied) and the minimum score was one for totally disagree (not satisfied).

The third part was mainly intended to collect data on women's suggestions for improving postpartum nursing quality (women were asked about potential changes required in the hospital to improve the quality of postnatal care).

An observation checklist was developed by the researchers for the nurses, after reviewing the relevant literature and $\mathrm{WHO}$ postnatal guidelines. It was used to assess the competence of nurses in practical skills applied to women from admission to postpartum ward to discharge. This checklist composed of 22 steps with three columns; (competent; incompetent; and not done). Competence indicated the care given which was in line with structured care. Incompetence means a lack of certain uniform treatment items. "Not done" means there is absolutely no care given.

\section{Validity and reliability}

For analysis and evaluation a jury consisting of three specialists in obstetric and a gynecological nursing was ascertained for the validity of the tool. The alpha coefficient of Cronbach was determined to assess the reliability of the established tool by means of its internal consistency. It was evaluated after the tool was developed and applied through a pilot study, which was performed on $10 \%$ of women to test the consistency, usability of the tool, and clarity, and to estimate the time required to fill in the tool.

\section{Field work and Ethical consideration}

An official letter was addressed from the Dean of the Faculty of Nursing, Port Said University to the directors of the selected study settings requesting their approval for data collection. Permission was obtained from each research setting, the researchers attended the selected settings (3 hospitals) six days a week) two days were allowed for each hospital over a period of six months from beginning of August 2017 to the end of January 2018 to collect the required data.

The consent of each women and nurse who clarified her intention to participate in the study was obtained verbally. Confidentiality was preserved by using a code number for each of them. They were assured about privacy of data collected by clarifying to them that it will be used only for the purpose of the study. As well, they were informed about voluntary participation and that they are allowed to withdraw from the study at any stage without giving any reason.

\section{Statistical analysis}

Data collected were tabulated and statistically analyzed using the statistical Package for Social Science (SPSS), version 20. Quantitative data were expressed a means \pm SD and quantitative data were expressed as numbers and percentages. Significance of the findings was regarded when $P$-value was $<0.05$ and highly significant when $P$-value $>0.001$.

\section{RESULTS}

Table 1 includes socio-demographic characteristics of the sample (mothers). The women's mean age is 29.01 years and the highest percentage $(67 \%)$ of them were in the 20-35-years age category. The same table indicates that slightly less than half (48\%) of women had primary or secondary school education, while more than three fourths $(78 \%)$ are housewives, and less than one third (35\%) stayed at the hospital 2 days and the length of hospital stay was 3 to 4 days for $40 \%$ of the women. As for family income, it was insufficient for $89 \%$. 


\section{Characteristics of the Women}

Table 1: Distribution of the Women according to their Profile $(n=300)$

\begin{tabular}{|l|c|c|}
\hline \multicolumn{1}{|c|}{ Personal characteristics } & No & \% \\
\hline Age (in years) & \multicolumn{2}{c|}{} \\
Less than 20 & 24 & 08.0 \\
$20-<35$ & 75 & 67.0 \\
$\geq 35$ & \multicolumn{2}{|c|}{29.01} \\
\hline Mean of age & 30 & \\
\hline Education level & 30.0 \\
No formal schooling & 144 & 10.0 \\
Primary / Secondary & 126 & 48.0 \\
University & & \\
\hline Job status & 234 & 78.0 \\
Housewife & 66 & 22.0 \\
Working & 33 & 11.0 \\
\hline Family income & 267 & 89.0 \\
Sufficient & & \\
Insufficient & 105 & 35.0 \\
\hline Period of current hospitalization (in days) & 120 & 40.0 \\
2 days & 75 & 25.0 \\
\hline 3-4 days & \\
\hline
\end{tabular}

\section{Socio-demographic Characteristics of the Nurses}

Table 2 displays the nurses' demographic characteristics. Fifty per cent of nurses age ranged between $26-<36 y e r s$. As for the educational level, $70 \%$ of them had a nursing diploma. Most of them $(82 \%)$ had less than five years of experience. The same table indicated that slightly less than two thirds (66\%) of nurses did not receive any post-partum training course. The same table denotes $18 \%$ of nurses were trained twice.

Table 2: Socio-demographic Characteristics of the Nurses $(n=50)$

\begin{tabular}{|l|c|c|}
\hline \multicolumn{1}{|c|}{ Personal characteristics } & No & \% \\
\hline Age (in years) & & \\
$<25$ & 24 & 48.0 \\
$26-36$ & 25 & 50.0 \\
$37+$ & 1 & 2.0 \\
\hline Education level & & \\
Nursing diploma & 35 & 70.0 \\
Specialty & 4 & 8.0 \\
Baccalaureate & 11 & 22.0 \\
\hline Duration of experience (in years) & & \\
$<5$ & 41 & 82.0 \\
6-10 & 6 & 12.0 \\
$>10$ & 3 & 6.0 \\
\hline Getting training course in post-partum care & & \\
yes & 17 & 34.0 \\
No & 33 & 66.0 \\
\hline Number of training courses (n=17) & 7 & 14.0 \\
One & 9 & 18.0 \\
Two & 1 & 2.0 \\
Three &
\end{tabular}

\section{Women's satisfaction with current postpartum care rendered to them}

Considering women's satisfaction with welcome, orientation and information, table 3.1 reveals that out of 300 women more than half $(56 \%$ and $52 \%)$ reported complete satisfaction with the welcome and orientation of their family visiting hours, while $72 \%$ and $46 \%$ were not satisfied with postnatal ward and bathroom orientation as well as nurses' information management and delivery. Asking the women about whether the staff nurses told them about what was going on, only a few percent $(0.5 \%)$ reported complete satisfaction.

Table 3 Percentage Distribution of the Women According to their Perception (agreement/ satisfaction) regarding postpartum care rendered to them $(n=300)$.

\section{Table 3.1: Welcome, Orientation and Information}

\begin{tabular}{|l|c|c|c|c|}
\hline \multicolumn{1}{|c|}{ Items } & $\begin{array}{c}\text { Totally } \\
\text { agree/ } \\
\text { FS (\%) }\end{array}$ & $\begin{array}{c}\text { Mostly } \\
\text { Agree/ } \\
\text { MS ( \%) }\end{array}$ & $\begin{array}{c}\text { Mostly } \\
\text { disagree/ } \\
\text { MnS (\%) }\end{array}$ & $\begin{array}{c}\text { Totally } \\
\text { disagree/ } \\
\text { NS (\%) }\end{array}$ \\
\hline $\begin{array}{l}\text { I was given a warm } \\
\text { welcome on } \\
\text { admission }\end{array}$ & 56.0 & 30.0 & 09.0 & 05.0 \\
\hline $\begin{array}{l}\text { I was oriented to } \\
\text { the postnatal ward } \\
\text { and bathroom }\end{array}$ & 03.0 & 05.0 & 20.0 & 72.0 \\
\hline $\begin{array}{l}\text { I was oriented } \\
\text { about visiting hours } \\
\text { for my family }\end{array}$ & 52.0 & 30.0 & 10.0 & 08.0 \\
\hline $\begin{array}{l}\text { I was informed } \\
\text { about informed } \\
\text { consent before } \\
\text { any procedure }\end{array}$ & 14.0 & 35.0 & 24.0 & 27.0 \\
\hline $\begin{array}{l}\text { Staff nurses kept } \\
\text { me informed about } \\
\text { what was happening } \\
\text { (preparation before } \\
\text { any procedure) }\end{array}$ & 05.0 & 24.0 & 25.0 & 46.0 \\
\hline $\begin{array}{l}\text { FS = Fully Satisfied, MS= Moderately Satisfied, MnS= Minimally Satisfied, } \\
\text { NS= Not Satisfied }\end{array}$ & & & \\
\hline
\end{tabular}

\subsection{Women's satisfaction with comfort, communication and values}

Slightly less than two thirds $(66 \%)$ of women felt either fully or moderately satisfied about being safe and secure during hospitalization, and $21.0 \%$ were fully satisfied as all questions were answered promptly with positive attitude, while the majority ( $82 \%)$ of women were not satisfied with the staff nurses as they did not dedicate enough time towards the patients. Just $15 \%$ of women were fully satisfied with postnatal ward 
cleanliness and furniture condition. Findings also revealed that only $22 \%$ of women reported to be fully satisfied about having positive memories of their experience in the postpartum period (Table 3.2).

Table 3.2: Comfort, Communication skills and Values

\begin{tabular}{|l|c|c|c|c|}
\hline \multicolumn{1}{|c|}{ Items } & $\begin{array}{c}\text { Totally } \\
\text { Agree/ } \\
\text { FS } \\
\text { (\%) }\end{array}$ & $\begin{array}{c}\text { Mostly } \\
\text { Agree/ } \\
\text { MS } \\
\mathbf{( \% )}\end{array}$ & $\begin{array}{c}\text { Mostly } \\
\text { Disagree/ } \\
\text { MnS } \\
\text { (\%) }\end{array}$ & $\begin{array}{c}\text { Totally } \\
\text { Disagree/ } \\
\text { NS } \\
\mathbf{( \% )}\end{array}$ \\
\hline $\begin{array}{l}\text { I felt staff nurses have sufficient } \\
\text { training to cope with women } \\
\text { satisfaction statuses }\end{array}$ & 00.0 & 10.0 & 15.0 & $75.0 \%$ \\
\hline $\begin{array}{l}\text { I felt safe and secured during my } \\
\text { hospital stay }\end{array}$ & 38.0 & 28.0 & 21.0 & 13.0 \\
\hline $\begin{array}{l}\text { There was no noise at night in the } \\
\text { ward }\end{array}$ & 05.0 & 20.0 & 35.0 & 40.0 \\
\hline $\begin{array}{l}\text { Cleanliness of the ward and } \\
\text { furniture condition }\end{array}$ & 15.0 & 40.0 & 36.0 & 09.0 \\
\hline $\begin{array}{l}\text { Nurses were calm and } \\
\text { approachable }\end{array}$ & 29.0 & 57.0 & 10.0 & 04.0 \\
\hline $\begin{array}{l}\text { Nurses communicated in my own } \\
\text { language and were free to talk }\end{array}$ & 23.0 & 40.0 & 27.0 & 10.0 \\
\hline $\begin{array}{l}\text { Staff nurses treated me with } \\
\text { dignity and respect }\end{array}$ & 24.0 & 42.0 & 25.0 & 09.0 \\
\hline $\begin{array}{l}\text { Staff nurses talked to me to find } \\
\text { my values and preference of care }\end{array}$ & 24.0 & 42.0 & 25.0 & 09.0 \\
\hline $\begin{array}{l}\text { Staff nurses devoted enough time } \\
\text { to me }\end{array}$ & 03.0 & 05.0 & 10.0 & 82.0 \\
\hline $\begin{array}{l}\text { Staff nurses devoted enough time } \\
\text { to my husband and relatives }\end{array}$ & 00.0 & 00.0 & 8.0 & 0.92 \\
\hline $\begin{array}{l}\text { All my question was answered } \\
\text { promptly with positive attitude }\end{array}$ & 21.0 & 37.0 & 26.0 & 16.0 \\
\hline $\begin{array}{l}\text { I felt that I handled the situation } \\
\text { well }\end{array}$ & 25.0 & 34.0 & 31.0 & 10.0 \\
\hline $\begin{array}{l}\text { Essential equipment, supplies and } \\
\text { drugs are available. }\end{array}$ & 23.0 & 25.0 & 38.0 & 14.0 \\
\hline $\begin{array}{l}\text { I have positive memories from } \\
\text { post-partum period }\end{array}$ & 22.0 & 47.0 & 18.0 & 13.0 \\
\hline FS Fuly Saisfed, & & & \\
\hline
\end{tabular}

$F S=$ Fully Satisfied, $M S=$ Moderately Satisfied, $M n S=$ Minimally Satisfied, $N S=$ Not Satisfied

\subsection{Specific Postpartum Care}

Forty percent of studied women were fully satisfied because nurses assisted them in early ambulation; 38\% about being informed regarding nutrition, sleep and rest in postpartum period; and $70 \%$ were fully satisfied for advices about the importance of day 40 follow up. On the other hand, women were not satisfied about advices on Lochia flow, abnormal neonatal condition, bonding and attachment along with information regarding child immunization were not received $(60 \%, 52 \%, 90 \%$ and $80 \%$, respectively) (Table 3.3 ).
Table 3.3: Specific Postpartum Care

\begin{tabular}{|c|c|c|c|c|}
\hline Items & $\begin{array}{c}\text { Totally } \\
\text { agree/ } \\
\text { FS } \\
\end{array}$ & $\begin{array}{c}\text { Mostly } \\
\text { Agree/ } \\
\text { MS } \\
\end{array}$ & \begin{tabular}{|c|} 
Mostly \\
disagree/ \\
MnS \\
\end{tabular} & $\begin{array}{c}\text { Totally } \\
\text { disagree/ } \\
\text { NS } \\
\end{array}$ \\
\hline $\begin{array}{l}\text { I was assisted to go to } \\
\text { the toilet and personal } \\
\text { hygiene }\end{array}$ & 14.0 & 35.0 & 24.0 & 27.0 \\
\hline $\begin{array}{l}\text { I was assisted in early } \\
\text { ambulation }\end{array}$ & 40.0 & 20.0 & 15.0 & 25.0 \\
\hline $\begin{array}{l}\text { I was explained how to } \\
\text { take care of minor } \\
\text { breast problem in } \\
\text { postpartum period }\end{array}$ & 19.0 & 25.0 & 19.0 & 37.0 \\
\hline $\begin{array}{l}\text { I was informed } \\
\text { regarding nutrition, } \\
\text { sleep and rest in } \\
\text { postpartum period }\end{array}$ & 38.0 & 27.0 & 18.0 & 17.0 \\
\hline $\begin{array}{l}\text { I was told regarding } \\
\text { lochia flow }\end{array}$ & 00.0 & 21.0 & 19.0 & 60.0 \\
\hline $\begin{array}{l}\text { I was advised about } \\
\text { post-natal activity }\end{array}$ & 42.0 & 22.0 & 14.0 & 22.0 \\
\hline $\begin{array}{l}\text { I was informed about } \\
\text { importance of post- } \\
\text { natal follow up }\end{array}$ & 70.0 & 23.0 & 15.0 & 02.0 \\
\hline $\begin{array}{l}\text { I was taught about the } \\
\text { importance of } \\
\text { colostrums/ breast } \\
\text { feeding }\end{array}$ & 12.0 & 30.0 & 28.0 & 30.0 \\
\hline $\begin{array}{l}\text { I was informed about } \\
\text { abnormal neonatal } \\
\text { conditions }\end{array}$ & 03.0 & 05.0 & 50.0 & 52.0 \\
\hline $\begin{array}{l}\text { I was taught about } \\
\text { bonding and } \\
\text { attachment }\end{array}$ & 00.0 & 00.0 & 10.0 & 90.0 \\
\hline $\begin{array}{l}\text { I was educated about } \\
\text { immunization }\end{array}$ & 00.0 & 08.0 & 12.0 & 80.0 \\
\hline $\begin{array}{l}\text { I was prepared for } \\
\text { discharge }\end{array}$ & 00.0 & 05.0 & 20.0 & 75.0 \\
\hline $\begin{array}{l}\text { I was informed about } \\
\text { postpartum follow up }\end{array}$ & 48 & 23 & 13 & 16 \\
\hline
\end{tabular}

$F S=$ Fully Satisfied, $M S=$ Moderately Satisfied, $M n S=$ Minimally Satisfied, NS $=$ Not Satisfied

Table 4 reveals that the highest percentage (30\%) were fully satisfied regarding furniture-related item and items related to health care provision $(22 \%)$, and the least for the items related to the services provided $(18 \%)$.

Table 4: Percent Distribution of the Study Women According to their Satisfaction Related to provided Services; Health Care Providers and Furniture Condition.

\begin{tabular}{|l|c|c|c|c|}
\hline \multicolumn{1}{|c|}{ Satisfaction } & $\begin{array}{c}\text { Fully } \\
\text { Satisfied } \\
\text { \% }\end{array}$ & $\begin{array}{c}\text { Moderately } \\
\text { Satisfied } \\
\%\end{array}$ & $\begin{array}{c}\text { Minimally } \\
\text { Satisfied } \\
\%\end{array}$ & $\begin{array}{c}\text { Not } \\
\text { Satisfied } \\
\%\end{array}$ \\
\hline $\begin{array}{l}\text { Items related to the } \\
\text { provided services }\end{array}$ & 18.0 & 30.0 & 14.0 & 38.0 \\
\hline $\begin{array}{l}\text { Items related to health } \\
\text { care providers }\end{array}$ & 22.0 & 30.0 & 26.0 & 22.0 \\
\hline $\begin{array}{l}\text { Items related to the } \\
\text { furniture condition }\end{array}$ & 30.0 & 20.0 & 15.0 & 35.0 \\
\hline
\end{tabular}


Table 5 exhibits women suggestions on how postpartum care services can be improved, the majority $(80 \%)$ of them suggested increasing the number of health care providers (staff), and $73 \%$ reported providing appropriate and enough postpartum advices. As well, less than half percent of them ( $46 \%$ and $48 \%$ ) of women suggested providing more neonatal care (i.e. baby bath) and improving hospital environmental sanitation respectively.

Table 5: Percent Distribution of the Studied Women according to their Suggestions for Improving PostPartum Care at the Hospitals

\begin{tabular}{|l|c|}
\hline \multicolumn{1}{|c|}{ Suggestions for improvement } & \% \\
\hline Conduct postpartum care follow-up (home visits) & 25.0 \\
\hline Engage women in their care (decision-making) & 30.0 \\
\hline $\begin{array}{l}\text { Attention must be paid to the emotional and economic } \\
\text { conditions. }\end{array}$ & 43.0 \\
\hline Provide more new natal care (baby bath) & 46.0 \\
\hline Improve hospital environmental sanitation & 48.0 \\
\hline Increase the number of health care providers (staff) & 80.0 \\
\hline $\begin{array}{l}\text { Provide appropriate and enough postnatal information } \\
\text { (advices) }\end{array}$ & 73.0 \\
\hline Recommended areas of information (73.0 \%) * & 70.0 \\
\hline Genital care & 45.0 \\
\hline Breast care & 73.0 \\
\hline Cord care & 20.0 \\
\hline Maternal-baby attachment and breast feeding & 66.0 \\
\hline Family planning & 47.0 \\
\hline Potential danger signs of postpartum &
\end{tabular}

* Recommended areas of information are not Mutually exclusive

Table 6 presents distribution of nurses according to their competencies in postpartum care. It shows that $61 \%$ of nurses were competent in checking regularly vital signs. Regarding postpartum breast and nipple inspection for engorgement, perineum examination and Lochia detection, and varicose vein legs were not done by $(70 \%, 60 \%$, and $72 \%$ respectively) nurses. While $42 \%, 57 \%$ and $21 \%$ of nurses were competent in encouraging women to move early, to drink hot fluid and in taking complete history in the postpartum period respectively. About the steps to prevent infection in the postpartum period, the same table reveals that $75 \%$ of nurses were competent in applying infection control measures (wearing gloves, hand hygiene, not recapping needles and others).
Table 6: Percentage Distribution of Nurses According their Competencies in Post Partum Care

\begin{tabular}{|c|c|c|c|}
\hline \multirow{2}{*}{ Items } & \multicolumn{2}{|c|}{ Performance } & \multirow{2}{*}{$\begin{array}{c}\text { Not } \\
\text { done } \\
\%\end{array}$} \\
\hline & $\begin{array}{c}\text { Competent } \\
\%\end{array}$ & $\begin{array}{c}\text { Incompetent } \\
\%\end{array}$ & \\
\hline \multicolumn{4}{|l|}{ Postpartum nursing care } \\
\hline Taking complete history & 37.0 & 46.0 & 17.0 \\
\hline $\begin{array}{l}\text { Explain any procedure to the } \\
\text { women }\end{array}$ & 03.0 & 20.0 & 77.0 \\
\hline Check vital signs regularly & 61.0 & 30.0 & 09.0 \\
\hline $\begin{array}{l}\text { Examination of breasts and nipple } \\
\text { for engorgement/ cracked }\end{array}$ & 10.0 & 20.0 & 70.0 \\
\hline $\begin{array}{l}\text { Examination of perineum and } \\
\text { observe Lochia }\end{array}$ & 20.0 & 20.0 & 60.0 \\
\hline Assess uterus & 02.0 & 04.0 & 94.0 \\
\hline $\begin{array}{l}\text { Examination of the legs for } \\
\text { varicose vein }\end{array}$ & 06.0 & 22.0 & 72.0 \\
\hline $\begin{array}{l}\text { Encourage the women to mobilize } \\
\text { as soon as appropriate following } \\
\text { birth }\end{array}$ & 42.0 & 22.0 & 36.0 \\
\hline $\begin{array}{l}\text { Give support to women during } \\
\text { initiation and continuation of } \\
\text { breast feeding }\end{array}$ & 03.0 & 26.0 & 71.0 \\
\hline $\begin{array}{l}\text { Encourage mothers to drink hot } \\
\text { fluid }\end{array}$ & 57.0 & 26.0 & 17.0 \\
\hline $\begin{array}{l}\text { Assess baby within one hour of } \\
\text { delivery }\end{array}$ & 13.0 & 36.0 & 51.0 \\
\hline \multicolumn{4}{|l|}{ Apply infection control measures } \\
\hline Follow infection control $\mathrm{m}$ easures & 75.0 & 15.0 & 10.0 \\
\hline \multicolumn{4}{|l|}{ Postpartum advices on } \\
\hline $\begin{array}{l}\text { Signs and symptoms of potential } \\
\text { life threatening }\end{array}$ & 04.0 & 37.0 & 59.0 \\
\hline $\begin{array}{l}\text { Importance of perineal hygiene, } \\
\text { frequent changing of sanitary pads }\end{array}$ & 00.0 & 00.0 & 100.0 \\
\hline Maternal nutrition & 38.0 & 45.0 & 17.0 \\
\hline $\begin{array}{l}\text { Return to fertility and s exual } \\
\text { activity }\end{array}$ & 00.0 & 10.0 & 90.0 \\
\hline Family planning & 33.0 & 40.0 & 27.0 \\
\hline Exclusive breast feeding & 00.0 & 00.0 & 100.0 \\
\hline $\begin{array}{l}\text { Essential newborn care and cord } \\
\text { care }\end{array}$ & 03.0 & 54.0 & 43.0 \\
\hline $\begin{array}{l}\text { Counseling on newborn danger } \\
\text { signs }\end{array}$ & 37.0 & 19.0 & 44.0 \\
\hline Immunization & 22.0 & 34 & 44.0 \\
\hline Growth monitoring & 00.0 & 00.0 & 100.0 \\
\hline
\end{tabular}

With respect to postpartum advices, table 6 also shows that more than one-third (38\%,33\% and 37\%) of nurses were competent in offering appropriate and sufficient health advices on maternal nutrition, family planning and infant danger signs, while most of nurses $(90 \%)$ did not provide health advices on returning to fertility and sexual activity and all of them on tracking baby growth monitoring. Also, $59 \%$ and $43 \%$ of nurses 
were not competent as they did not teach the women about potential life-threatening signs, essential newborn care, and cord care respectively.

Table 7 presents the relation between quality of postpartum care and nurses' profile (selected variables). It indicates that there were no statistically significant differences between nurses' profile (age, years of experience in obstetric and gynecological units \& training courses) and postpartum care rendered, applying infection control measures and post-partum advices.

Table 7: Relation Between Quality of Postpartum Care and Nurses' Profile (selected variables)

\begin{tabular}{|c|c|c|c|}
\hline Items & $\begin{array}{c}\text { Rendered } \\
\text { Postpartum } \\
\text { Ng. care }\end{array}$ & $\begin{array}{c}\text { Apply infection } \\
\text { control } \\
\text { measures }\end{array}$ & $\begin{array}{c}\text { Postpartum } \\
\text { advices }\end{array}$ \\
\hline $\begin{array}{c}\text { Age (years) } \\
\text { Mean } \pm \text { SD } \\
\boldsymbol{P}=\end{array}$ & $\begin{array}{c}4.84 \pm 0.21 \\
0.777\end{array}$ & $\begin{array}{c}4.80 \pm 0.31 \\
0.316\end{array}$ & $\begin{array}{c}1.98 \pm 1.8 \\
0.617\end{array}$ \\
\hline $\begin{array}{c}\text { Years of experience } \\
\text { (in Ob/Gyn. units) } \\
\text { Mean } \pm \text { SD } \\
\boldsymbol{P}=\end{array}$ & $\begin{array}{c}4.85 \pm 0.21 \\
0.467\end{array}$ & $4.80 \pm .31$ & $1.97 \pm 0.17$ \\
& 0.453 & 0.801 \\
\hline $\begin{array}{c}\text { Training courses } \\
\text { Mean } \pm \text { SD } \\
\boldsymbol{P}=\end{array}$ & $4.85 \pm 0.21$ & $3.62 \pm 0.32$ & $1.97 \pm 0.17$ \\
& 0.187 & 0.989 & 0.855 \\
\hline \multicolumn{2}{|r|}{} \\
\hline
\end{tabular}

Table 8 indicates a fairly high overall total mean of female satisfaction ( $3.90 \pm 0.62)$, whereas the highest mean (4.10 \pm 0.46$)$ was for comfort, communication skills and values, followed by advices provision $(3.83 \pm 1.8)$, then welcome, orientation and information $(3.80 \pm 1.00)$ and the least pleased was for specific nursing care $(1.32 \pm 0.46)$.

Table 8: Mean Satisfaction According to the Different Areas of Nursing Care

\begin{tabular}{|c|c|}
\hline Areas of Nursing Care & Mean \pm SD \\
\hline Orientation and information & $3.80 \pm 1.00$ \\
\hline Comfort, communication skills and value & $4.10 \pm 0.46$ \\
\hline Advices provision & $3.83 \pm 1.8$ \\
\hline Specific nursing care & $1.32 \pm 0.46$ \\
\hline Total women satisfaction & $3.90 \pm 0.62$ \\
\hline
\end{tabular}

Table 9 indicates a positive and highly significant correlation between post partum women's satisfaction and competence of nursing care rendered $(P<0.001)$.

Table 9: Correlation Between Competences of Rendered Nursing Care and Postpartum Women Satisfaction

\begin{tabular}{|l|c|c|}
\hline \multirow{2}{*}{ Women's satisfaction } & \multicolumn{2}{|c|}{ Competence of nursing care rendered } \\
\cline { 2 - 3 } & $r$ & $p$-value \\
\cline { 2 - 3 } & 0.334 & $0.001^{*}$ \\
\hline
\end{tabular}

\section{DISCUSSION}

The relevant research has shown that both the mother and the child will have certain health concerns during the immediate postpartum period as most maternal and newborn deaths occur during this period. Thus, it is a crucial time in life as these must be carefully treated with high quality of care. Sensibly, women's satisfaction is an important indicator of maternity health care quality and in medical and nursing literature for that it has received great attention.

With regard to women's socio-demographic characteristics, the results of this study revealed that the highest percentage of women's age ranged between 20$<35$ years representing two thirds with a mean age of 29.01. As for education, more than two fifths of them were university graduates, while a minority representing one tenth had no formal schooling. This is presumed because the proportion of university education is rising in Port Said city and the studied women in reproductive age.

Upon childbirth, women need to live in health care facilities for long enough to receive adequate treatment. In the current study, about two fifths of women, the duration of hospital stay was 3 to 4 days. This finding disagreed with that of a study conducted in Canada by Campbell et al. (2016), while this is longer in a study conducted by Lomoro et al., (2002), which reported that the average hospitalization time for those born by caesarean birth was six days. Such variations could be due to the characteristics of the facility, the provider and/or the characteristics of the participants. Nonetheless, the World Health Organization suggests that all women stay in healthcare centre at least 24 hours postpartum (WHO, 2013). The researchers believe that, despite this suggestion, women leave or are made to leave facilities quickly in many settings before essential postpartum checks can take place. Additionally, Brown et al., (2004) reported that prolonged stay may increase exposure to adverse environment facilities, with increased the risk of nosocomial infections, sleep disturbance, or poor support for infant feeding that may reduce parental involvement, or family bonding.

Concerning satisfaction of the women with rendered postnatal services: With regard to the first domain of women's satisfaction with treatment given (welcome orientation and information) in the present study; it was evident that more than half of women expressed their full satisfaction with the worm welcome on admission and orientation about their family visiting hours. However, less than three-quarters were not satisfied with postnatal 
ward and bathroom orientation. In addition, when asked if the staff nurses told them about what was going on i.e. preparation before any procedure, only a minority of women expressed full satisfaction.

These findings correspond to those stated by Alidosti, Tahmasebi \& Raeisi, (2013) in Iran, which showed that women's satisfaction with the welcome was strong. As well Rudman et al., (2008), research found that more than half of the women interviewed were disappointed with the inadequacy of nurses training because they had not been aware of the procedural. Most of the clients were not greatly pleased with employee behavior. These findings require further investigation to identify challenges of nurses face in gaining the skills required for patient's orientation. Postpartum women, generally, need appropriate guidance and knowledge about the type of care they receive and the postpartum programs. It allows them to be friendly and look for early publicity. In that respect, Takacs et al., (2015) indicated that, in order to improve satisfaction with maternity care in hospitals, the key efforts should be directed mainly to assisting midwives in providing information to workers working in maternity care as trust has been gained and converted into higher satisfaction scores.

Regarding the second domain of women's satisfaction with treatment provided (comfort, communication skills and values); if a supportive caregiver attitude has been established, then client finds the hospital safe enough for future use as clarified by Lamadah \& El-Nagger, (2014). The present study had shown that slightly less percentage of patient felt either fully or moderately satisfied about being safe and secure in contact with the nurses and health provision during hospital stay. Otherwise, the study indicated that two fifths of women were not satisfied with the services at night in the ward and the majority of them were not satisfied about staff nurses' not devoting enough time to the patients. This finding was inconsistent with an earlier study conducted by Elgazzar \& Hashem (2018) on Egyptian women who found that slightly more than twothirds of the women surveyed were pleased with the contact from nurses.

In this context, results of the current study revealed that all respondents indicated that if the nurses treated them with dignity and respect then interpersonal relationships with their caregivers were good (politeness, compassion, empathy, safety and security provision), they would be pleased with their treatment even if other factors had not been addressed. From this context, a study was conducted at the health centers affiliated to Tehran
University of Medical Sciences (Iran) by Mirzaei et al., (2016), which evaluated the level of patient satisfaction with the verbal and non-verbal communication skills of midwives. The study reported that nearly half of the studied mothers were moderately satisfied with the communication skills of midwives. The current study findings disagreed with those of previous study conducted by Mohammed (2016) at Jordan that found than less percent $(13 \%)$ of women were satisfied with interpersonal communication. These differences in findings may be due to women's perception and expectations.

As regards the third area of women's satisfaction with rendered care (specific post partum care), i.e. women's satisfaction with basic postpartum treatment. Results of the current study revealed that more than half of the mothers received postnatal care, while most of them were not taught about bonding and attachment as well as the majority of women were not educated about child immunization. In disagreement, Mohammed (2016), who examined maternal satisfaction regarding quality of nursing care during labor and delivery in Sulaimani Teaching Hospital, reported that women were satisfied with their care during labor and delivery. However, Lamadah \& El-Nagger (2014) reported that most mothers were not happy with the postpartum treatment and discharge plan guidance. The reasons of the research finding may differ for several factors: firstly, the birth of a healthy baby may offset negative experiences; secondly, the timing of evaluation, exhaustion and postpartum pain may cause women not to be focused on nursing care and, finally, hospitalized postpartum mothers may be hesitant to question the services they have been provided as providers were still involved.

The findings of this study showed that near two fifths of postnatal mothers were not satisfied with postnatal services, such as guidance on postnatal selfcare practices; restriction and attachment; teaching on abnormal neonatal conditions and infant immunization. About three-quarters of women also reported that they were not prepared for discharge and absolutely not satisfied or pleased. The findings of the current study are in agreement with those of Takacs et al., (2015), who discovered that in the Czech Republic hospitals, mothers were unhappy with postpartum hospital education due to lack of time and the amount of information needed to prepare new mothers and their families was not sufficient for the treatment of newborn children at home. These differences in outcomes can be linked to women's brief hospital stay in Port-Said City 
after birth which negatively affects the nurse's role in addressing effectively the learning needs of a new mother. Stays of less than 24 hours in the last few years have been encouraged in some settings as mentioned by Ware (2015) and Campbell et al., (2016). In Egypt, after giving vaginal birth, the average woman remaining in the hospital is half a day.

In the present study, regarding women's satisfaction with postpartum treatment, about half of women were either fully satisfied or moderately satisfied with the services provided, and lightly more than fifth were not satisfied with the health care providers. The actual study results were in line with Varghese \& Rajagopal (2013) who measured the level of maternal satisfaction with the care services received in the postpartum unit and stated that half of the mothers surveyed were satisfied with the quality of the postpartum education and training. The study assessed maternal satisfaction with respect to six sides of satisfaction with the organization of the health center's human resources, equipment and supplies, overall satisfaction with care services, satisfaction with the level of comfort during hospitalization, overall satisfaction with the health workers ' care services and mother preferences in this regard. Mohammed (2016), who carried out a study also denoted that the origins of client frustration with postpartum treatment include hospital setting characteristics as non-availability of support and material resources, such as facilities, and financial issues.

Incongruent with the previous results, several studies as that of Nikpour et al., (2007) who measured the degree of maternal satisfaction with the standard of prenatal care services showed that $91.7 \%$ of mothers were pleased with the postpartum services provided. Similarly, Kojuri et al., (2005), conducted a study on women, and found that $87.2 \%$ of the participants were satisfied with the quality of postnatal treatment. Inevitably, insufficient and poor-quality treatment will have a negative effect on the health outcomes and happiness of mothers.

Furthermore, lack of information or support within facilities for women can reduce maternal confidence or cause problems with breastfeeding, postpartum depression or care dissatisfaction as mentioned in a study carried out by Ware (2015). During the hospital stay, information about self-care and newborn care given to new mothers can minimize concerns and boost satisfaction with increase in levels of confidence (Takaes et al., 2015).
In accordance with the current study findings, Okonufua et al., (2017) surveyed eight secondary and tertiary hospitals in Nigeria and confirmed that many of the mothers were or were not at all satisfied with the quality of antenatal, intrapartum and postnatal. The importance of implementing a discharge plan was studied by Lamadah \& El-Nagger (2014). Mothers' satisfaction regarding quality of postpartum nursing care and a discharge teaching plan showed improved satisfaction in postpartum care. Previous study done by Kebalepile (2001) showed that the key obstacles are understaffing and insufficient financing of health facilities at the township and village level. With regard to the relationship between the competence of rendered aftercare and the profile of the nurses under study as age, years of experience in Obstetrics and gynaecology training courses, no statistically significant relationship were detected between the profile of the nurses (studied variables) and the postpartum care provided. On the contrary, Abd El Fattah, Negawa, \& El Dein, (2009) found that there is a relationship between the expertise of nurses and their practice of immediate postpartum. Over half of nurses have strong knowledge and practice in preparing delivery supplies, delivering immediate neonatal care, assisting women in providing safety and comfort, rest, sleep, exercise, nutrition and health education.

Post-natal advices and knowledge continue to be a critical process and unique step among new mother's and her baby's life. In this study nurses in these advice areas were incompetent or are not aware of the information related to return of fertility, sexual activity, baby growth monitoring, as well as instruction of the women about symptoms of potential life threaten and essential newborn care along with cord care respectively.

A very recent study carried out by Wickramasinghe, Gunathunga \& Hemachandra, (2019) stated that, patient satisfaction is correlated with rendered nursing care. Regarding the correlation between the competences of postpartum rendered nursing care and level of satisfaction, the current study findings showed that, there was a positive and highly statistically significant difference between the competence of rendered nursing care and postpartum women's satisfaction. Consistent with the results of the current study, similar previous studies, showed a strong positive relationship between nursing care and patient satisfaction (Azizi-Fini et al., 2012; Akhtari-Zavare et al., 2010). However, no statistically significant relationship exists between the competencies of the nurses and the satisfaction of the 
patients. The discrepancies in previous and current results could be attributed to differences in areas of study, as well as the time of the studies.

\section{CONCLUSION}

According to the results of this study, there was a statistically significant difference between the competences of rendered nursing care and postpartum women's satisfaction. Furthermore, competence-based nursing care should be provided after the cesarean birth for mothers in the postpartum unit to provide appropriate nursing care.

\section{RECOMMENDATIONS}

Future studies may focus on how postpartum mothers see the care they receive and the type of care they need to improve their satisfaction with the services they are provided.

\section{REFERENCES}

Abd El Fattah, N., Negawa, A. \& El Dein, Z. (2009). Assessment of quality of nursing care provided immediately after birth at university hospital. Life Science Journal, 9(4), pp 2115-266.

Abdel Maqsood, S., Oweis, I. \& Hansa, S. (2012). Differences between patients' expectations and satisfaction with nursing care in a private hospital in Jordan. International Journal of Nursing Practice, 18, pp 140-146.

Akhtari-Zavare, M., Abdullah, Y., Hassan, S., Said, B. \& Kamali, M. (2010). Patient satisfaction: Evaluating nursing care for patients hospitalized with cancer in Tehran teaching hospitals, Iran. Global Journal of Health Science, 2(1), pp 117.

Alidosti, M., Tahmasebi, M. \& Raeisi, M. (2013). Evaluating the women's satisfaction of Hajar Hospital services after the delivery. Journal of Clinical Nursing and Midwifery, 2(1), pp 1-8.

Alsaqri, S. (2016). Patient satisfaction with quality of nursing care at governmental hospitals, Ha'il City, Saudi Arabia. Journal of Biology, Agriculture and Healthcare, 6(10), 128-142.

Azizi-Fini, I., Mousavi, M.S., Mazroui-Sabdani, A. \& Adib-Hajbaghery, M. (2012). Correlation between nurses' caring behaviors and patients' satisfaction. Nursing and Midwifery Studies, 1(1), pp 36-40.

Brown, S., Bruinsma, F., Darcy, M.A., Small, R. \& Lumley, J. (2004). Early discharge: No evidence of adverse outcomes in three consecutive population-based Australian surveys of recent mothers, conducted in 1989, 1994 and 2000. Paediatric and Perinatal Epidemiology, 18(3), pp 202-213.

Buchanan, J., Dawkins, P. \& Lindo, J.L.M. (2015). Satisfaction with nursing care in the emergency department of an urban hospital in the developing world: A pilot study. International Emergency Nursing, 23, pp 218-224.

Campbell, O.M., Cegolon, L., Macleod, D. \& Benova, L. (2016). Length of stay after childbirth in 92 countries and associated factors in 30 low- and middle-income countries: Compilation of reported data and a cross-sectional analysis from nationally representative surveys. PLoS Medicine, 13(3):e1001972.

Dzomeku, M., Ba-Etilayoo, A., Perekuu, T. \& Mantey, E. (2013). In patient satisfaction with nursing care: A case study at Kwame Nkrumah University of Science and Technology Hospital. International Journal of Research in Medical and Health Sciences, 2(1), pp 19-24.

Elgazzar, H.M. \& Hashem, S, A.R. (2018). Factors affecting women's satisfaction during labor experience. Port Said Scientific Journal of Nursing, 5(2), pp 220-236.

Enabor, O, Nwaeze, I. \& Ouwasola, T. (2013). Perception \& satisfaction of the quality of antenatal care among pregnant women in Nigeria. Annual of Ibadan Postgraduate Medicine Journal, 1(11), pp 140-52.

Freitas, D., Silva, C., Minamisava, R., Bezerra,. Q. \& Sousa, D. (2014). Quality of nursing care and satisfaction of patients attended at a teaching hospital. Revista latino-americana de Enfermagem, 22(3), pp 454-460.

Goh, I., Ang K., Chan, H., He, G. \& Vehvilainen, K. (2016). A descriptive quantitative study on multiethnic patient satisfaction with nursing care measured by the revised humane caring scale. Applied Nursing Research, 31, pp 126-131. 
Herculano, M.M, Veloso, L.S, Teles L.M, Oriá, M.O., de Almeida, P.C. \& Damasceno A.K. (2012). Maternal deaths at a public maternity hospital in Fortaleza: An epidemiological study. Revista da Escola de Enfermagem, 46(2), pp 295301.

Kebalepile, M. (2001). An evaluation of the quality of care midwives provide during the postpartum period in Northern Botswana (Master's thesis). University of Oslo, Oslo, pp 22.

Kojuri, D., Karimi, H., Shekarabi, R. \& Hossinei, F. (2005). A study of satisfaction with prenatal care services in the women attending to the health centers of the Shirevan Chardavel (IRAN), in 2005. Iran Journal of Nursing, 18(43), pp 61-69.

Lamadah, S. \& El-Nagger, S. (2014). Mothers' satisfaction regarding quality of postpartum nursing care and discharge teaching plan at Ain Shams Maternity and Gynecological Hospital. International Journal of Current Research, 6(7), pp 7545-51.

Lomoro, O., Ehiri, E, Qian, X. \& Tang, L. (2002). Mother's perspectives on the of postpartum care in Central Shanghai, China, Oxford Journals. International Journal for Quality in Health Care, 14(5), pp 393-401.

Matejić, B., Milićević, Š., Vasić, V. \& Djikanović, B. (2014). Maternal satisfaction with organized perinatal care in Serbian public hospitals. BMC Pregnancy and Childbirth, 14(1), pp 14.

McLellan, J. \& Laidlaw, A. (2013). Perceptions of postnatal care: Factors associated with primiparous mother's perceptions of postnatal communication and care. BMC Pregnancy and Childbirth, 13:227.

Merkouris, A., Andreadou, A., Athini, E., Hatzimbalası, M., Rovithis, M. \& Papastavrou, E. (2013). Assessment of patient satisfaction in public hospitals in Cyprus: A descriptive study. Health Science Journal, 7(1), pp 28-40.

Mirzaei, K., Oladi, G.S., Mousavi, B.M. \& Ziaee, M. (2016). Mother's satisfaction of postpartum care and its relationship with midwifery care at Urban Health Centers, Mashhad, Iran. Journal of Midwifery and Reproductive Health, 4(3), pp 679-688.

Mohammed, K. (2016). Maternal satisfaction regarding quality of nursing care during labor and delivery in Sulaimani Teaching Hospital. International Journal of Nursing and Midwifery, 8(3), pp 18-27.

Monazea, M. \& Al-Attar, S. (2015). Quality of delivery care in Assiut University Hospital, Egypt: Mothers' satisfaction. Journal of the Egyptian Public Health Association, 90(2), pp 64-71.

Nikpour, S., Shahpourian, F., HajiKazemi, S., Hosseini, H. \& Safdari, M. (2007). The relationship between women's satisfaction with prenatal care services and characteristics of the women and the provision of services. Iran Journal of Nursing, 20(49), pp 15-27.

Okonofua, F., Ogu, R., Agholor, K., Okike, O., Abdus-Salam, R., Gana, M. \& Galadanci, H. (2017). Qualitative assessment of women's satisfaction with maternal health care in referral hospitals in Nigeria. Reproductive Health, 14(1), pp 44.

Rudman, A., El-Khouri, B. \& Waldenström, U. (2008). Evaluating multi-dimensional aspects of postnatal hospital care. Midwifery, 24(4), pp 425-441.

Shinde, M. \& Kapurkar, K. (2014). Patient's satisfaction with nursing care provided in selected areas of tertiary care hospital. International Journal of Science and Research, 3(2), pp 150-160.

Singh, M., Parashar, M. \& Lal, P. (2018). Life satisfaction and correlates among working women of a tertiary care health sector: A cross-sectional study from Delhi, India. Medical Journal of Dr. D. Y. Patil Vidyapeeth, 11, pp 406-11.

Şişe, Ş. (2013). Hastaların hemşirelik hizmetlerinden memnuniyeti [Satisfaction of patients with nursing care]. Kocatepe Tip Dergisi, 14, pp 69-75.

Spector, J.M., Agrawal, P., Kodkany, B., Lipsitz, S., Lashoher, A. \& Dziekan G. (2012). Improving quality of care for maternal and newborn health: Prospective pilot study of the WHO Safe Childbirth Checklist Program. PLoS ONE, 7(5), e35151.

Srivastava, A., Avan, B.I., Rajbangshi, P. \& Bhattacharyya, S. (2015). Determinants of women's satisfaction with maternal 
health care: A review of literature from developing countries. BMC Pregnancy and Childbirth, 15(1), 97.

Takács, L., Seidlerová, J.M., Šulová, L. \& Hoskovcová, S.H. (2015). Social psychological predictors of satisfaction with intrapartum and postpartum care-what matters to women in Czech maternity hospitals? Open Medicine, 10(1), pp 119-127.

Tang, W.M., Soong, C.Y. \& Lim, W.C. (2013). Patient satisfaction with nursing care: A descriptive study using interaction model of client health behavior. International Journal of Nursing Science, 3(2), pp 51-56.

Tsuboi, S., Uehara, R., Oguma, T., Kojo, T., Enkh-Oyun, T., Kotani, K. \& Ohashi, Y. (2014). Satisfaction with hospital care among diabetic outpatients and its associated factors. Secondary use of official statistics. [Nihon koshu eisei zasshi] Japanese Journal of Public Health, 61(10), pp 613-624.

Varghese, J. \& Rajagopal, K. (2013). Development of a new tool for evaluating postnatal mother's satisfaction following nursing care: In India. Journal of Biology, Agriculture and Healthcare, 3(9), pp 37-44.

Ware, R.N. (2015). Improved satisfaction on postpartum unit by implementing a discharge Nurse Role. Master's Projects and Capstones. The University of San Francisco, USF Scholarship: a digital repository @ Gleeson Library, Geschke Center, pp 1-28.

Wickramasinghe, A., Gunathunga, W. \& Hemachandra, N. (2019). Client perceived quality of the postnatal care provided by public sector specialized care institutions following a normal vaginal delivery in Sri Lanka: Across sectional study. BMC Pregnancy and Childbirth, 19(1), pp 485.

World Health Organization (2011). Strengthening Midwifery Tool kit: Module 4 Competencies for midwifery practice. Retrieved from: http://whqlibdoc.who.int/publications/2011/97892 41501965_module4_eng.pdf.

World Health Organization (2013). WHO recommendations on postnatal care of the mother and newborn, Geneva: World Health Organization.

You, L., Aiken, H., Sloane, M., Liu, K., He, G. \& Hu, Y. (2013). Hospital nursing, care quality and patient satisfaction: Cross-sectional surveys of nurses and patients in hospitals in China and Europe. International Journal of Nursing Studies, 50, pp 154-161. 